\title{
ECOCRITICISM AND TRANSLATION ${ }^{1}$
}

\author{
Carmen Valero Garcés, Universidad de Alcalá - GIECO Instituto Franklin \\ Email: carmen.valero@uah.es
}

\begin{abstract}
This article is about literature, culture and landscapes with the addition of translation. My intention is twofold. First I aim to call the attention of Ecocriticism to the importance of translated texts as main texts; secondly, I will emphasise the opening of a new perspective in Translation Studies related to this new way of thinking about the relationships between literature and place when translating it. In order to perform this task, Walden, a significant piece of work in Ecocriticism, by D. H. Thoreau, and some translated versions of this work into Spanish are the object of study.First I will introduce Ecocriticsm by providing some definitions of related concepts and brief notes on its development; then I will briefly illustrate the importance of translation in the building of a new area to finally show the interconnections between these two areas, and exploring their consequences analysing Walden and its translations into Spanish.

Keywords: Translation; Ecocriticism; Literature; Landscape, Walden, Thoreau .
\end{abstract}

Title in Spanish: Ecocrítica y traducción

Resumen: Este artículo trata sobre literatura, cultura y paisajes con la adición de la traducción. Mi intención es doble. En primer lugar mi objetivo es llamar la atención de la Ecocrítica sobre la importancia de la traducción en el nacimiento de una nueva disciplina; y, en segundo lugar, quiero hacer hincapié en la apertura de una nueva línea de investigación en los Estudios de Traducción al aplicar los presupuestos de la Ecocrítica a la traducción de textos relacionados con la cultura, la literatura y el medio ambiente. Para llevar a cabo esta tarea, utilizare como ejemplo Walden, de D.H. Thoreau y su traducción al español. En primer lugar, haré una breve introducción sobre la Ecocrítica, proporcionando algunas definiciones de conceptos relacionados y su desarrollo; en segundo lugar, trataré de ilustrar brevemente la importancia de la traducción en la construcción de una nueva área de estudio como es la Ecocrítica. Finalmente buscaré interconexiones entre estas dos áreas a través del análisis de Walden, una de las obras mas significativas en Ecocrítica y sus traducciones al español.

Palabras clave: Traducción, Ecocrítica, Literatura, Medio ambiente, Walden, Thoreau.

\section{ECOCRITICISM: LITERATURE AND LANDSCAPE}

Generally speaking, Ecocriticism is the study of literature and environment from an interdisciplinary point of view. It is a relatively new field of enquiry and no consensus has emerged yet regarding its definition. Its beginning is officially recognized by the

Date of reception: 15 June 2011

Date of acceptance: 12 July 2011

Odisea, ${ }^{\circ} 12$, ISSN 1578-3820, 2011, 257-272 
publication of two seminal works, both published in the mid-1990s: The Ecocriticism Reader, edited by Cheryll Glotfelty and Harold Fromm, and The Environmental Imagination, by Lawrence Buell. Cheryll Glotfelty (1996) defined ecocriticsm as 'the study of the relations between literature and the environment' and Lawrence Buell defined it as "[a] study of the relationship between literature and the environment conducted in a spirit of commitment to environmentalist praxis" (1995: 20), adding a more practical dimension.

As for the main objectives of this recent area of study, Glotfelty, in her article 'Literary Studies in an Age of Environmental Crisis' (1996: xix), clearly set out the main objective of Ecocriticism: the interconnectedness between nature and culture, specifically the cultural artifacts of language and literature. However, since then the concept has evolved new concepts and approaches have risen. Thus, David Mazel (2000: 1) calls ecocriticism the study of literature "as if the earth mattered", and Simon Estok (2001: 16-17) argues that ecocriticism is more than "simply the study of Nature or natural things in literature; rather, it is any theory that is committed to effecting change by analyzing the function-thematic, artistic, social, historical, ideological, theoretical, or otherwise-of the natural environment, or aspects of it, represented in documents (literary or other) that contribute to material practices in material worlds". While Camilo Gomides (2006: 16), offered a more operational definition to attract scholars from the sciences: "The field of enquiry that analyzes and promotes works of art which raise moral questions about human interactions with nature, while also motivating audiences to live within a limit that will be binding over generations".

More recently Lynch $(2008: 13)$ wrote that "Ecocriticism is (...) the study of the manifold interrelationships between literature - a human expressive activity- and the natural world that provides the matrix in which that expressive activity occurs". And it continues arguing that ecocriticism "is concerned with showing how literature is embedded within and mutually symbiotic with the encompassing more-than-human world that enables, enriches, sustains, alters, and in turn is altered by it", and concluding that ecocriticism works "to shift the focus of literary studies from an antropocentric focus to an ecocentic one". An example is Xerophilia (2008), a book where he applies such a diverse approaches as environmental justice theory, phenomenology, conservation biology, environmental history, and ecoaesthetics, to demonstrate how a rooted literature can be symbiotic with the world that enables and sustains it. Analysing works in a variety of genres by southwest American writers his study reveals how these writers, as community storytellers, contribute to a sustainable bioregional culture (the emphasis is mine) that persuades inhabitants to live imaginatively, intellectually and morally in the arid bioregions of the American Southwest, as Slovic (2008: $\mathrm{xx}$ ) points out in the foreword of the book.

This concept of bioregion is defined by Rober L. Thayer's (2003:3) as follows: “A bioregion is literary and etymologically a "life-place"- a unique region definable by nature (rather than political) boundaries with a geographical climatic, hydrological, and ecological character capable of supporting unique human communities". And Kikpatrick Sale (1991: 42) says the task of bioregionalism is to teach us how to "become dwellers in the land". Thus, bioregion, according to Sale, is the most logical locus and scale for a sustainable, regenerative community to take root and to take place, and, of course, language is also present.

As Lynch (2008: 30) points out, all languages carry the imprint of their bioregions of origin. Or said in a different way, specific languages evolved to help people living in a 
particular place discuss that place with others living in the same place. This means that, as people migrate to new places, new gaps may open between language and place, and the more the new place differs from the place of origin, the more problematic could be the fit between world and world. That is, landscape has an influence in the development and the use of language, and when its speakers migrate to new places, a contrast between the new space and the language takes place. It is a contrast which may mean disconnection or severance that will grow when bigger the contrasts are between the new and the old landscape or environment.

The speaker may notice that there is lack of words, or that he/she can not express an idea and needs search for words whose meaning is similar to the one in the text, or he/she must use other linguistic strategies such as explanations, metaphors, images, etc.

All this can be reflected in an explicit way but we often do it in a more implicit and contrastive way, and, consciously or unconsciously, the old territory serves us as a model or normative terrain with the new one, as Lynch (2008: 31) states.

Mary Austin's comment in the preface to The Land of Journeys' Ending [1924] (1969, viii-ix) is highly illustrative:

The topography of the country between the Colorado River and the Rio Grande cannot be expressed in terms invented for such purposes in a low green island by the North Sea. A barranca is terrifyingly more than an English bank on which the wild thyme grows; an arroyo resembles a gully only in being likewise a water gouge in the earth's surface, and we have no word at all for cañada, half way between an arroyo and a cañon, whichthough, naturally, you have been accenting the syllable that best expresses the trail of the white man across the Southwest- is really pronounced can-yon.

There are also terms such as abra, playa, encerro, which cannot be English at all except by the use of more words than you will have time for when you attempt to inquire your way about the country.

Following Austin's use of Spanish words in English texts, Lynch (2008: 32) comments that Spanish is a language more suited to portraying the arid bioregions of American Southwest than English because:

To begin with, Spain is a more arid country, and so a language that evolved there would necessarily be more suited to describing another, even a distant, arid region. Second, the Spanish language is heavily influenced by Arabic, a language that evolved in even more arid circumstance.

Even if, as a translator I may or may not completely agree, what these comments illustrate is the influence of the environment in the language. An example is provided by Austin (1969 ix) cit in 2008:33) when talking about the word 'desert', a term that itself usually defines a place by what it lacks rather than by what it possesses. A word that itself encodes an absence, not a presence, and implies that deserts are inherently and by definition deficient, and I should say, negative. "Deserts are deserted" she said. But this is not necessarily always the case. Thus Steven J. Phillips and Patricia Wentworth Comus 
(2000,9-10) in their work A Natural History of the Sonoran Desert provide a definition of the word 'desert' that will alter this sort of perception:

A desert is a biological community in which most of the indigenous plants and animals are adapted to chronic aridity and periodic, extreme droughts, and in which these conditions are necessary to maintain the community's structure.

Terry Tempest William $(2001,136)$ in his essay entitled "Red" also writes:

The relationship between language and landscape is a marriage of sound and form, an oral geography, a sensual topography, what draws us to place and keeps us there. Where we live is the center of how we speak.

Tom Lynch's discussion of Henry David Thoreau's famous list of life's essentials, composed on the shore of Walden Pond in Massachusetts - and offered so emphatically in the "Economy" chapter of Walden: food, shelter, clothing, and fuel, - while visiting a favourite cave ("La Cueva") in the Organ Mountains near las Cruces, New Mexico provides an illustrative example. Lynch thinks about this list of necessities and wonders, drinking from his water bottle, what it is missing from such a list, there in the middle of the desert. This is an example to show how a core text in the genre of environmental writing is so deeply connected to the specific dimensions of a particular landscape and climate that some of its central claims might not be applicable to other parts of the world, such as the desert Southwest, where water is the single most obvious necessity. As Slovic comments (2008: $\mathrm{xv}$ ), Walden might have become a different book if Thoreau had lived in Las Cruces.

The same may happen when considering a typical Spanish landscapes: the countryside of Castilla of Antonio Machado, the olive trees of Miguel Hernández, the lagoons of Blasco Ibañez or Jarama river of Sánchez Ferlosio as the significance of the Spanish history. Another example is the interest of the Spanish 'Generation 98' for landscapes (See Martinez Pison, Imagen del paisaje. La Generacion del 98 y Ortega y Gasset) Azorín, who in his El paisaje de España visto por los españoles writes: "El paisaje somos nosotros; el paisaje es nuestro espíritu, sus melancolías, sus placideces, sus anhelos, sus tértegos (23). ("We are the landscape; the landscape is our spirit, its melancholy, its calmness, its yearnings, its tértego [traduccion propia]).

The landscape becomes an essential tool to understand the psychology of the Spanish people in a particular historical moment, as it happened with Campos de Castilla by Antonio Machado or Cañas y Barro by Blasco Ibanez.

However, each glance and every action reveals every single landscape, and its translation is an action, a change through which the common becomes novel or exotic, and vice versa.

In regards of this Tuan (2007: 87) writes in Topofilia that to understand the priorities of an individual with respect to the environment, we should study her/his biological heritage, the way s/he has been raised by, her/his education, work and material surrounding.

Regarding the attitudes and priorities of a group, Tuan likewise reckons that the cultural history of an individual and her/his experience in the material surrounding must be taken into account.

Odisea, $n^{\circ} 12$, ISSN 1578-3820, 2011, 257-272 
What I want to show with by these examples is the importance of the environment that surrounds us because each bioregion has its own characteristics which undoubtedly have an influence on culture, and on the way it is portrayed and expressed. Moreover, each of us has array of sensations, smells, reactions or images which we share with others of our environment.

\section{ECOCRITICISM AND TRANSLATION}

The question is what happens when the landscape is translated- taken to another bioregion with a language and different culture; what position does the translator adopt? Does s/he 'see' the same landscape, does s/he perceive the same smells and senses as the author of the source text (ST)? Or, on the contrary, does the translator go beyond the borders of the bioregionalism and transfer the text to a new ecological reality?

If language is a means of transporting this reality, one has to bear in mind that languages are not mirrors which overlap each other. In every day language we find gaps, empty spaces, other similar overflows. But there are also special vocabularies (terminology) and new words that need to be adapted by the speakers and unified even in the same language. The discussion about the best term to be used to name this new field of study in the mid 1990 is a good example as explained by Cheryll Glotfelty in her introduction to The Ecocriticism Reader en 1996. Three were the main terms under discussion: "literary ecology", "environmental literature", and "ecocriticism", and the same discussion has passed to other languages as is the case of the Spanish, where it is still an open question (Flys, Marrero \& Barella 2010: 15-25).

Tuan dedicates one chapter of four pages in his book Topofilia to the word "wilderness" (109-112). This word is repeated in the English version 34 times in four pages; the Spanish translation of this word appears in 13 different ways which are shown in the following chart.
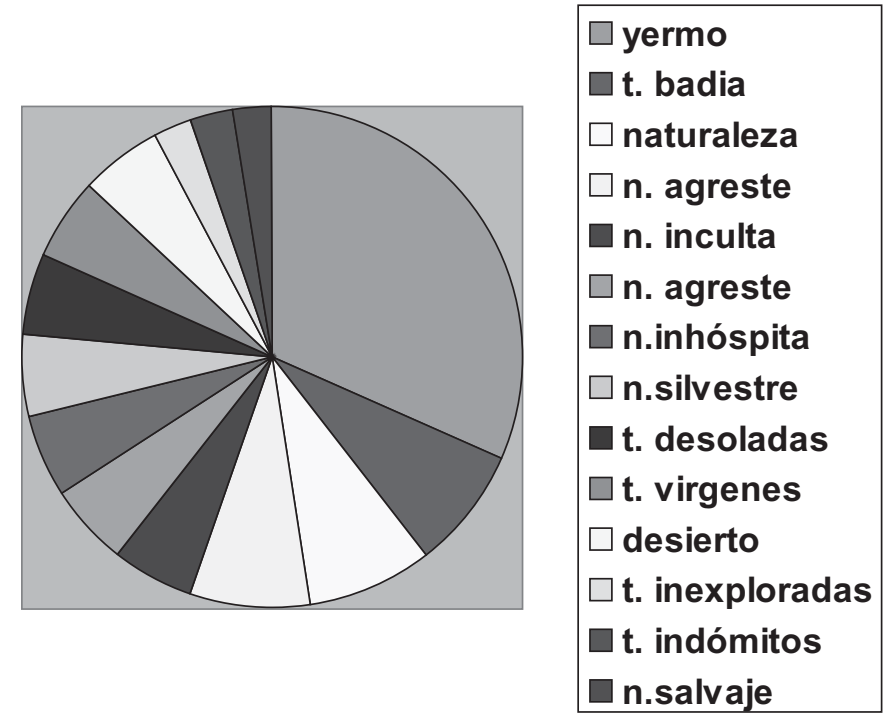

Odisea, ${ }^{\circ} 12$, ISSN 1578-3820, 2011, 257-272 
We observe that the most used words are "wilderness", "nature" used in different ways, "lands", "territories" and "deserts", however, the images which these concepts evoke are not necessarily the same. Even just paying attention to their denotative meaning, in which case, using the dictionary of the Spanish Real Academia (22 th edition) as a source of information, we find, for example, in the case of "wilderness " three entries: 1. uninhabited, 2. uncultivated; 3 . uninhabited land.

Likewise, the images which might evoke compound words as "wild nature" or "inhospitable nature", for instance, do not mean necessarily the same. It was sufficient to ask 3 or 4 people of my surrounding. All of them agreed that there were certain connotations in these words which differed.

Spivak shows us another example. In her translation to the English language of Mahasweta Devi's book written in Bengali Imaginary Maps, Spivak introduces a preface and translator's note (xxiii). At the beginning of the preface she appreciates Mahawseta Devi, the author, the comments and help with the revision of the translated text. This allows her to talk about an authorized translation ("an authorized translation"). Spivak says that the book Imaginary Maps will be published in India and the USA - two different bioregions, "at the same time". This leads her to state that she is aware that these are two distinct communities, and in the moment of translating or entering the comments she must bear in mind both communities. The comment which Spivak adds at the end of her preface to Imaginary Maps clearly illustrates this debate:

Sujit Mukherjee has also complained - and this is particularly important for US readers who are looking for either local flavour or Indian endorsement- that the English of my translation is not "sufficiently accessible to readers in this country [India]". This may indeed be true, but may not be sufficient grounds for complaint. I am aware the English of my translations belongs more to the rootless American-based academic prose than the more subcontiental idiom of my youth. This is an interesting question, unique to India: should Indian texts be translated into the English of the subcontinent? I think Sri Mukherjee is begging rather than considering this question. (xviii)

As we already mentioned, bearing in mind that the area known as Ecocriticism merged in USA, we live under a great influence of Anglo-Saxon world in terms of words, expressions, set phrases, and titles that can be heard at international conferences held by associations as EASCLE (European Association for the Study of Literature, Culture and the Environment), or ASLE (Association for the Study of Literature and Environment) as for instance "bioregional environment", "compassion fatigue", "human materiality", "commodification", “transcorporality”, “eco-humanism”, “ecophobia”, "presentism”, “deterritorialization”, "speaking nature", "ecocosmopolitanism", "translocation", "eco-masculinity", "animality", "polymorphously activist", "climate justice", "ecological holism", "cultural criticism", planetarity", "radical ecology", "biosemiotic". "queering the non/human", "conversive and coopetitive", "dark ecology", etc. This variety of new words illustrate the complexity of thea translator's task who should have a deep thought about the best way to bring them into a new language and culture - or say, a new bioregion. (Valero Garcés 2010: 121-134).

The above discussed examples clearly illustrate some of the challenges such as transporting the sceneries, changing between bioregions and the need to bear the clarity 
in mind. A review of the environmental, original or translated Spanish literature from the Ecocriticism's point of view offers richness for the investigation. There are already some outstanding examples (Marrero 2010, Barella 2010).

As for translation, statistics show that the percentage of people-including students, public in general, and researchers- that read literary works in a different language than that in which they were originally written is a highly productive market.

It is also worth mentioning again the origin of Ecocriticism (USA) and its introduction in Spain (English departments of universities) to understand that translation is a necessary tool in both directions. It is necessary both to bring the works of the founders and representatives of this movement to the Spanish language, as to take the investigation of the Spanish ecocritics into the English language.

However, when talking about the quality of translations, or the authors of these translations (the translators themselves), the literature is either non-existent or, if practiced at all, is carried out in a subjective, undisciplined, ad hoc fashion, as Martínez Melis and Hurtado (2001) point out.

It is also difficult to find any reference to translation in environmentalists and ecocritics' papers or even in associations like the already mentioned EASCLE or ASLE, whose main purpose, as it is stated in the introduction to the association, is

(...) to facilitate interdisciplinary and innovative approaches to the study of nature and culture through forms such as nature writing, art, ecocritical scholarship, pedagogy, science writing, poetry, music, creative writing, and film, among other forms.

When translation is mentioned, comments do not usually go further than intuitive opinions of the type: "The translation does justice to the original", or "the translation does not reproduce the author's style", and so on.

If we take as a point of departure that of a foreign spectator reading a translated book, some questions arise: Which landscape does the reader see? How is the source text (ST) landscape depicted in this 'new version'? Does it really reflect the same image as in the ST? Has the translator intervened? How? Has s/he been influenced by the ST cultural bioregion? Have time, space, politics or the translation trends of his/her time influenced at all?.

Coming back to Terry Tempest William's (2001: 136) statement in Red- "Where we live is the center of how we speak" - and the topic of this work- translating literary texts related to nature - a question which merges what happens when we have to bring into our landscape / bioregion texts which are not part of it. The analysis of one of the masterpieces of the environmental literature: Walden by H.D. Thoreau and their translation into the Spanish may provide some answers.

\section{THE AUTHOR, HIS TIME AND THE RECEPTION OF TRANSLATED TEXT}

Henry David Thoreau was born in Concord, Massachusetts July 12, 1917. He is one of the best representatives of American Romanticism, naturalism, transcendentalism, tax resister, and development critic. His writing on natural history and philosophy anticipated the methods and findings of ecology and environmental history, two sources of modern 
environmentalism and ecocriticsm. Thoreau's books, articles, essays, journals, and poetry sum a total of over 20 volumes. Two of his main works are Walden or Life in the Woods (1854), a reflection upon simple living in natural surroundings, and his essay Civil Disobedience, an argument for individual resistance to civil government in moral opposition to an unjust state.

As for the Spanish reception of Walden, surprisingly enough for an author who is so difficult to translate into other languages, Thoreau is quite well known in Spain. This is especially true - as Casado da Rocha points out (2008)- of certain circles: environmental and animal rights activists, pacifists and civil disobedients, political activists, philosophers with a taste for heterodoxy. Thoreau is also known in certain academic circles because Walden has traditionally being one of the compulsory readings for the students of English Philology.

As a translated text, there are several versions chronologically mentioned in the following lines:

1907: The earliest Spanish translation of Walden is the chapter 'Solitude', which appeared in the magazine Renacimiento, $\mathrm{n}^{\circ} 2$, Madrid. In a review of this edition, Antonio Machado wrote that "every Spanish intellectual should read this book, and learn it by heart, for Thoreau was an intellectual who dreamed as a Latin man does, but turned his dreams into reality as an Anglo-Saxon" (Cif. Justo Gárate, in his introduction to his translation of Walden, 1949).

1945: Walden o la vida en los bosques. Translated by Julio Molina y Vedia. Buenos Aires: Emecé.

1949: Walden o mi vida entre los bosques y lagunas. Translated by Justo Garate. Buenos Aires: Espasa Calpe.

1976: Walden o la vida en los bosques. Translated by H. Quinto. Barcelona: Producciones J. J. Fernandez Ribera.

1977: Walden, Life in the Woods, edited by Antonio Saldaña, and published in Mexico (Premia Edt.). This book is an exact copy of the first complete translation of Walden translated by Julio Molina y Vedia in 1945.

1979/1983/2002: Walden o la vida en los bosques. Translated by Carlos SánchezRodrigo. 1st ed. Madrid: Ediciones del COTAL; 2nd ed. Barcelona: Parsifal; 3rd ed. San Cugat del Vallés: Amelia Romero.

2005: Walden. Edited and translated by Javier Alcoriza and Antonio Lastra. Madrid: Cátedra

As for Thoreau's biography, Justo Gárate, member of the Thoreau Society, published in 1970 Thoreau in the Spanish Language (Thoreau Society Booklet no. 24). Justo Gárate was a Basque exile who translated Walden in 1949 and found the first recorded mention of Thoreau in the writings of the philosopher Miguel de Unamuno, who shared with Thoreau contempt for the news that "a ready wit might write a twelve month or twelve years beforehand with sufficient accuracy" (Gárate, 1970: 94-5), and also comparing this situation with the state of affairs in Spain in the $19^{\text {th }}$ century. Gabriel Celaya, Juan Ramón and Antonio Machado also knew Thoreau and Walden.

In 2004, Antonio Casado da Rocha published Thoreau, Biografia esencial. It includes a chapter about Walden and an up-to-date bibliography.

Odisea, $n^{\circ} 12$, ISSN 1578-3820, 2011, 257-272 


\section{LANDSCAPES OF WALDEN INTO SPANISH}

For this study I have chosen four translations of Walden. Each translation is given a letter in order to facilitate the reading. This analysis will provide us with images of Walden landscapes into Spanish. The order will be the following:

A: The translation by Julio Molina y Vedia, published in 1945 with the title Walden o la vida en los bosques, and being the first complete translation produced into Spanish and published in Buenos Aires.

B: The translation by Justo Gárate (B), published in 1949 also in Argentina (Colección Austral) with the title Walden o mi vida entre bosques y lagunas.

C: The translation by Carlos Sánchez-Rodrigo published first in 1979 and later in 1983 with the title Walden o la vida en los bosques. It is the first complete translation I have found published in Spain, and the one most widely used till recently. A new edition was published in 2002.

D: The translation by Javier Alcoriza y Antonio Lastra, published in 2005 by Cátedra with the short title of Walden (Thoreau had eliminated the subtitle of Life in the Woods in 1862). It is the most recent version of Walden

A and B were published in Argentina and C and D in Spain. It is worth mentioning at this point that from the 1940s until the mid 1950s, it was a time when in Spain it was difficult to publish literature due to Franco's political regime. In this period, most of the North American Romantics (Hawthorne, Melville, Emerson, Thoreau) were translated in Latin America, being these first translations the only ones that Spanish readers had access to for a long time (See the article 'De la Argentina llegó un barco cargado de muchos libros para la curiosidad lectora de los españoles, in La Estafeta Literaria, 25, 25 April: 1945: 21).

As already said, Walden is a difficult book to be translated at all levels, not only linguistically but also because it represents the projection of the Massachusetts landscape, and projects a specific image that is brought to another language and culture by the translator.

To illustrate the difficulties found by translators and the different solutions taken, as well as the results of these decisions, some examples follow:

Example 1

ST: Internally, whether in the globe or animal body, it is a moist thick lobe, a word especially applicable to the liver and lungs and the leaves of fat $(\lambda \varepsilon \dot{\beta} \beta \omega$, labor, lapsus, to flow or slip downward, a lapsing; $\lambda$ oßós, globus, lobe, globe; also lap, flap, and many other words); externally a dry thin leaf, even as the $f$ and $v$ are a pressed and dried $b$. The radicals of lobe are $\mathrm{lb}$, the soft mass of the $\mathrm{b}$ (single lobed, or $\mathrm{B}$, double lobed), with the liquid 1 behind it pressing it forward. In globe, glb, the guttural $g$ adds to the meaning the capacity of the throat.(546)

A: Internamente, sea en el globo o cuerpo animal, es un lóbulo húmedo, palabra especialmente aplicable al hígado, a los pulmones y a las leaves (hojas) de grasa ( $\lambda$ cí $\beta \omega$, labour, lapsus, correr o resbalar hacia abajo, un deslizarse; $\lambda$ oßós, globos, lóbulo, globo; también lap (1), flap (2) y muchas otras palabras); externamente, una seca y delgada leaf (3), como si la f y la v fuesen una b prensada y secada. Las raíces de lobe (4) son lb, la blanda de al b (de simple lóbulo), o de la B (de doble lóbulo), con una líquida 1 detrás, 
impulsándola para adelante. En globe (globo), la gutural g añade al significado la capacidad de la garganta. (303)

Footnotes in the ST:

-En inglés: lamer, bañar (el agua); labrar (joyas o metales); envolver, rodear.

- Batir, colgar.

- Hoja.

-Lóbulo. (N. de T.)

B. Internamente, sea en el orbe o en el cuerpo animal, es un lóbulo espeso y húmedo, palabra que se aplica especialmente al hígado y a los pulmones y las leaves (1) de grasa

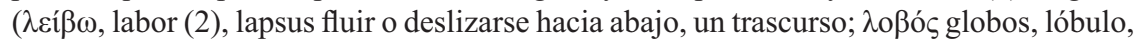
globo; de igual manera lap, (3) flap (4) y otras muchas palabra). Externamente, una leaf (5) seca y delgada, de la misma manera que la f y la $\mathrm{v}$ (6) son una b comprimida y seca. Los radicales de lóbulo son $\mathrm{lb}$, la blanda masa de la b (la de un solo lóbulo), o de la B (de dos lóbulos), con una 1 líquida tras ella empujándola hacia adelante. En globo, hay glb, y la gutural g añade al significado la capacidad de la garganta (275)

Footnotes:

(1) Hojas. Trad.

(2) Labor, laberios, verbo latino para deslizarse. Trad.

(3) Colgajo. Trad.

(4) Falda, etc. Trad.

(5) Hoja. Trad. Citada sin duda porque leaves es el plural de leaf. Trad.

C: Internamente, tanto en el globo como en el cuerpo de animal, no es sino un lóbulo grueso y húmedo, imagen especialmente aplicable al hígado y a los pulmones y a los panículos de grasa $(\lambda \varepsilon \dot{i} \beta \omega$, ) labor, lapsus, flujo o corrimiento hacia abajo, caída; $\lambda$ oßó $\varsigma$ globus, lóbulo, globo; también lap (1) y flap (2) y muchas otras palabras); externamente, una hoja seca y delgada, hasta porque la $\mathrm{f} y \mathrm{v}$ (3) no son sino una $\mathrm{b}$ comprimida y disecada. Las consonantes de lób(ul)o son lb, la suave masa de la b (monolobulada o de B bilobulada), con una 1 líquida detrás, que la empuja adelante. En globo, glb, donde la gutural g suma al significado el apoyo de al garganta. (258)

Footnotes

(1) Colgajo

(2) Falda

(3) Leaf $=$ hoja (pl. leaves)

D. Internamente, sea en el globo o en el cuerpo animal, es un lóbulo espeso y húmedo, una palabra especialmente aplicable al hígado y a los pulmones y a los panículos de grasa $(\lambda \varepsilon i ́ \beta \omega)$, labor, lapsus, fluir o deslizarse, un lapso; $\lambda$ oßó $\varsigma$ globos, lóbulo, globo; también regazo, falda y muchas palabras); externamente una hoja delgada y seca, como si la h y la $\mathrm{j}$ hubieran presionado y secado la b. Las consonantes del lóbulo son lb, la suave masa de la b (sencilla, o B, doble) con una 1 líquida detrás de ella que la empuja hacia adelante. En globo, glb, la gutural que añade al significado la capacidad de la garganta. (332)

No footnotes

When comparing the translations, we find the translators have opted for different strategies such as:

Odisea, $n^{\circ} 12$, ISSN 1578-3820, 2011, 257-272 
a) copying directly from English the Latin and Greek words and adding footnotes;

b) maintaining the words in English and adding footnotes (A and B);

c) maintaining some, translating some others and adding footnotes (C);

d) translating all the words and adapting the texts, as in the case of 'leaf', and the phonological constraints imposed by the two systems.

The question is: do all the four translations provoke the same image in the TL reader?.

Example 2 refers to a well-known fact: the use of different temperature systems in the USA (Fahrenheit) and Europe (Celsius or centigrade)

ST: A thermometer thrust into the middle of Walden on the 6th of March, 1847, stood at $32^{\circ}$, or freezing point; near the shore at $33^{\circ}$; in the middle of Flint's Pond, the same day, at $321^{1}{ }^{\circ}$ at a dozen rods from the shore, in shallow water, under ice a foot thick, at $36^{\circ} .(540)$

A: Un termómetro echado al medio del Walden el 6 de marzo de 1847 se mantuvo a $32^{\circ}$ (F); y cerca de la costa a $33^{\circ}$; en el medio del lago de Flint, el mismo día, el termómetro marcaba $32 \frac{1}{2}{ }^{\circ}(\mathrm{F})$, y a una docena de varas de la costa, en poco agua, bajo un hielo de un pie de espesor, a $36^{\circ} .(296)$

B: Un termómetro sumergido en el centro de Walden el 6 de marzo de 1847, alcanzó $0 \%$, o sea, el punto de congelación; sumergido cerca de la orilla, señaló $0 \%$ y 5 ; ; en el centro de la laguna de Flint, el mismo día, $0^{\mathrm{a}}$ y $2^{\prime}$; aun docena de varales desde la ribera, en agua poca honda, bajo hielo de un pie de espesor, $2^{\circ}$. (269)

C: Un termómetro situado en mitad de sus aguas el 6 de marzo de 1847 señaló $32^{\circ}$, es decir, el punto de congelación; (5) situado cerca de la orilla a $33^{\circ}$; introducido el mismo día en el centro de la laguna de Flint, marcó $32,5^{\circ}$; y a doce perchas de la orilla, allí donde el agua no es muy profunda, bajo palmo y medio de hielo, señaló $36^{\circ}$. (253)

D: Un termómetro instalado en el centro de Walden el 6 de marzo de 1847 se mantuvo a cero grados, en el punto de congelación; cerca de la orilla marcó cero grados y medio. En el centro de la laguna de Flint, el mismo día, $0,2^{\circ}$; a una docena de varas de la orilla, en aguas someras, bajo hielo de un pie de espesor, $2,7^{\circ}$. (325).

The different temperature systems oblige the translator to take some decisions. Thus A adds the symbol (F) of Fahrenheit the first time the temperature is mentioned so the reader can infer the exact temperature without making the mistake of associating the number with Celsius centigrade. Thus, B prefers to adapt the temperature to the Celsius System, according to the formula to convert Fahrenheit into Celsius: Substract 32 and multiply by $5 / 9$ (five ninths). C simply copies the numbers, without introducing any indication. D adapts the temperature to Celsius.

The following examples $(3,4,5,6)$ show the different lexical choices for the same word / phrase in English as taken by the different translators. These selections guide the reader towards the drawing of a different image too: 
Example 3

ST: (...) with a regular honk from the leader at intervals. (553)

A: (...) con un jonk de su conductor emitido a intervalos regulares. (309)

B: (...) con un graznido regular de su conductor de vez en cuando. (280)

C: (...) mientras el guía emitía sus 'jonk' a intervalos regulares. (263)

D: (...) con un graznido regular del guía. (338)

The example above shows that A and C prefer directly copying the English word ('jonk'), a tendency that is followed in other parts of the book, while B and D prefer to look for the Spanish equivalent and use 'graznido'.

Something similar happen in the following examples:

Example 4:

\begin{tabular}{|l|l|l|l|l|} 
ST & A & B & C & D \\
\hline $\begin{array}{l}\text { The cracking } \\
\text { and booming of } \\
\text { the ice indicate } \\
\begin{array}{l}\text { a change of tem- } \\
\text { perature. (541) }\end{array}\end{array}$ & $\begin{array}{l}\text { La crepitacióny } \\
\text { los estampidos } \\
\text { del hielo. (298) }\end{array}$ & $\begin{array}{l}\text { La rajaduras y } \\
\text { los estallidos del } \\
\text { hielo. (270) }\end{array}$ & $\begin{array}{l}\text { Los crujidos y } \\
\text { crepitaciones del } \\
\text { hielo. (254) }\end{array}$ & $\begin{array}{l}\text { Las grietas y es- } \\
\text { tallidos del hielo. } \\
\text { (237) }\end{array}$ \\
& & &
\end{tabular}

Example 5:

\begin{tabular}{|l|l|l|l|l|}
$\mathrm{ST}$ & $\mathrm{A}$ & $\mathrm{B}$ & $\mathrm{C}$ & $\mathrm{D}$ \\
\hline (...) the sides of & (...) al resbalar & B: (..) los & C: (...) la pen- & D: (...) los \\
a deep cut on the & por los lados de & taludes de una & diente de una & costados de un \\
railroad. (546) & un profundo tajo & trinchera profun- & profunda hendi- & profundo socavón \\
& en la vía férrea. & da del ferrocarril. & dura sobre la vía & del ferrocarril. \\
& (301) & férrea. (256) & (328)
\end{tabular}

Example 6:

\begin{tabular}{|l|l|l|l|l|}
$S T$ & A & B & C & D \\
\hline $\begin{array}{l}\text { Sandy rupture } \\
\text { (547) }\end{array}$ & reventazones & $\begin{array}{l}\text { grietas arenosas } \\
\text { arenosas (302) }\end{array}$ & $\begin{array}{l}\text { grietas mezclada } \\
\text { con arena (257) }\end{array}$ & $\begin{array}{l}\text { resquicio arenoso } \\
(332)\end{array}$
\end{tabular}

As seen in these examples, the lexical choice guide the reader towards the drawing of an image than can be quite different from one to another, or from the one suggested by the ST. Thus, the translator can make the reader feel more closely to the nature (bioregion) through these decisions portraying the ST, or he can try to bring the ST to his own natural environment. We observe that 'crepitaciones', 'rajaduras', 'crujidos' o 'grietas' are used as synonyms for 'cracking' - or that 'tajo', 'trinchera', 'hendidura' and 'socavón' are used for 'cut'. But if we look up their meaning in the Spanish authoritative dictionary of Real Academia we found that 'socavón' or 'trinchera', for instance, are not even synonyms, and the image which they evoke is not the same as if we read the ST and we are familiar with Walden and its environment. The same happens with the translation of "sandy rupture" 
where the words as 'reventazones' turns out very little usual in the peninsular vocabulary or where 'grietas' and 'resquicio' are not synonyms if we analyze each component.

A special chapter is the translation of passages containing names of animals and plants. The influence of bioregionalism may be seen in the choice of some bird names when the specie does not exist in Spain or are not common in other countries than in North America. The chart below contains the different alternatives taken by the different translators (Example 7):

\begin{tabular}{|l|l|l|l|l|} 
ST: & $\begin{array}{l}\text { Molinay } \\
\text { Vedia,1945 }(A)\end{array}$ & Gárate, $1949(B)$ & $\begin{array}{l}\text { Sánchez Rodrigo, } \\
1979(C)\end{array}$ & $\begin{array}{l}\text { Alcoriza y Lastra, } \\
2005(D)\end{array}$ \\
\hline Bluebird & Azulejo & Pájaro azul & Ruiseñor azul & Azulejo \\
\hline Red-wing & Malvas & Malviz & Turpial de dorso rojo & Mirlo \\
\hline Snipe & Becarón & Agachadiza & Chocha & Agachadiza \\
\hline $\begin{array}{l}\text { Brown } \\
\text { thraster }\end{array}$ & Calandria & Malviz roja & Tordo de wilson & Malviz parda \\
\hline Wood pewee & Papamosca & Tirano & Tirano de los bosques & $\begin{array}{l}\text { Papamoscas de } \\
\text { los bosques }\end{array}$ \\
\hline Phoebe & Febe & Febe & Papamoscas & Aguador \\
\hline
\end{tabular}

Such a variety of birds obviously may lead to different images for the TT reader, and it obliged the translator to make some decisions because: 1 . Not all the birds mentioned in ST are found in Europe; 2. The different words given by the translators to a single English bird are not necessarily synonyms in Spanish nor do they represent the English bird; 3. Some of the Spanish words refer to Latin American birds, and they are not necessarily known in Spain. 4. Some solutions taken may also be due to regional differences. 5. Diachronic distance may also have some influence.

If we analyse the decisions of the translators from the ecocritic's point of view we can say that there are versions in which the translator approaches more to the bioregion of the ST (e.g. A) while in other versions the translator seems to approach to the natural environment of his/her own environment (e.g. D). In the first case we could speak of "source text bioregion - oriented approach" while in the second we could call it a "target text bioregion - oriented approach".

A similar situation is found when referring to flora as the next table shows:

The comparison is showed in the table below (Example 8):

\begin{tabular}{|l|l|l|l|l|} 
ST & A & B & C & D \\
\hline Goldenrods & Romerillo & goleen rods & olidazos & varas de oro \\
\hline Pinweed & Pinweed*(1) & pinweeds & junquillos & Jaras \\
\hline Hard-hack & Coronas de novia & hard hacky & corazoncillo & corazoncillo \\
\hline Weeds & yuyos*(3) & hierbas & plantas discretas & un velo *(4) discreto \\
\hline
\end{tabular}

Again we see a variety of names in Spanish for the same English word. Two translations (A and D) introduce some footnotes. In the case of A to explain certain direct calques by using the Latin word, and also to explain (in footnote 3 ) the double meaning of 'weeds', 
as it also happens with the footnote in D. B uses a few direct calques, but no explanation is provided. $\mathrm{C}$ translates all the words. Reading Thoreau's passage and then reading the TT, A reveals that the translator prefers the use of words directly copied from the ST (e.g. pinweed, cotton-grass, johnsworts, or wool-grass), and the use of footnotes. In this case we find the scientific terms,- the best way to identify the plant by the scientist or expert,- but it makes it difficult for the non-expert TT reader to know which plant Thoreau is talking about.

Finally I will include another example that reveals some interesting discourse aspects, and may even suggest some differences due to linguistic, stylistic or even diachronic aspects, but also due to the bioregional influence or "life-place" (Thayer 2003:3).

Example 9:

ST: When the ground was partially bare of snow, and a few warm days had dried its surface somewhat, it was pleasant to compare the first tender signs of the infant year just peeping forth with the stately beauty of the withered vegetation which had withstood the winter - life-everlasting, goldenrods, pinweeds, (...). (548)

A. Cuando el suelo estaba parcialmente desnudo de nieve y unos pocos días templados habían secado un poco su superficie, era un placer comparar los primeros signos tiernos del año infante, recién asomado con su belleza majestuosa entre la vegetación marchita que había resistido al invierno: la siempreviva, el romerillo (...). (306)

B: Cuando la tierra estaba desprovista parcialmente de nieve y unos cuantos días cálidos habían secado algo su superficie, era agradable comparar los primeros signos tiernos del año infantil que entonces se muestran con la belleza regia de la vegetación marchita que resistió el invierno- siempre vivas, golden rods...(...). (277)

C: Cuando el suelo queda parcialmente libre de nieve y su superficie se ha secado algo por efecto de los día tibios, me era grato buscar las primeras señales del tiempo nuevo que atisbaban apenas al exterior entre la majestuosa belleza de la vegetación ya marchita que logró resistir al invierno: siemprevivas, olidazos.... (260)

D: 'Cuando la tierra estaba parcialmente despejada de nieve y algunos días habían secado su superficie, era agradable comparar la primeras señales tiernas de la niñez del año que entonces asomaban con la belleza majestuosa de la vegetación marchita que había resistido al invierno: las siemprevivas, las varas de oro... .' (334)

When comparing the ST with the translations, it is easy to perceive the poetic effect of these lines in English and the different effect that the translations might produce in the target reader. A and B shows certain pragmatic and textual weakness and tendency toward word for word translation, which reduce efficiency of the text; while $\mathrm{C}$ and $\mathrm{D}$ reveal a more target text-oriented approach, suggesting a more dynamic equivalence or bioregional closeness. They are also the more recent versions and the ones produced in Spain, two circumstances that might have some influence in the TT that would need to be explored.

In short, analyzing the translation from the new perspective of Ecocriticism might lead the translation critic or reader to a different conclusion. This analysis would allow us to know if the image of a landscape that a TT reader's draws in his/her mind corresponds 
to the same image of the landscape that the ST portrays, or if by changing the place and language of expression the image transmitted by the TT has also changed.

Concluding, I have tried to establish connections between Ecocriticism and Translation Studies and call the attention to some of the challenges and difficulties the translator faces when bringing texts from different bioregions; but also to call the attention to the ecocritics towards the power of translation in the building of a new area of research and study.

\section{REFERENCES}

Austin, M. 1969. The Land of Journey's Ending. New York: AMS Press [1924].

Azorin, A. 1942. El paisaje de España visto por los españoles. Madrid: EspasaCalpe.

Barella, J. 2010. "Naturaleza y paisaje en la literatura española". Ecocríticas. Literatura y medioambiente. C. Flys, J. M. Marrero AND J. BARElla eds. Madrid: Iberoamericana. 219-238.

Buell, L. 1995. The Environmental Imagination: Thoreau, Nature Writing, and the Formation of American Culture. Cambridge, MA and London, England: Harvard University Press.

Estok, S. C. 2005. 'Shakespeare and Ecocriticism: An Analysis of 'Home' and 'Power' in King Lear.” AUMLA 103 (May 2005). 15-41.

Flys, C., J. M. Marrero and J. Barella, 2010. "Ecocríticas: el lugar y la naturaleza como categorías de análisis". Ecocríticas. Literatura y medioambiente. C. Flys, M. MARRERo and J. BARELLAD eds. Madrid: Iberoamericana. 15-25.

Glotfelty, Ch. 1996: "Literary Studies in an Age of Environmental Crisis". The Ecocriticism Reader: Landmarks in Literary Ecology. Ed. Ch.Glotfelty and H. Fromm. Athens, Georgia: University of Georgia Press. xix.

Gomides, C. 2006. "Putting a New Definition of Ecocriticism to the Test: The Case of The Burning Season, a film (mal)Adaptation". ISLE 13.1 (2006): 13-23.

LA ESTAFETA LITERARIA 1945: "De la Argentina llegó un barco cargado de muchos libros para la curiosidad lectora de los españoles" no 25, April 25: 21.

LyNCH, T. 2008. Xerophilia. Ecocritical Explotarions in Southwestern Literature. Texas: Texas Tech University Press.

Marrero, J. M. 2010. "Ecocrítica e hispanismo". Ecocríticas. Literatura y medioambiente. C. Flys, J. M. MARrero and J. BARELla eds. Madrid: Iberoamericana. 193-218.

Martínez Melis, N. and Hurtado, A. 2001: “Assessment in Translation Studies: Research Needs", Meta, 46, 2: 272-287.

Martinez Pison, E. 1998. Imagen del paisaje. La Generacion del 98 y Ortega y Gasset. Madrid: Caja de Ahorros y Monte de Piedad de Madrid. 
Mazel, D. 2000. American Literary Environmentalist. Athens Georgia: Georgia University Press.1

Phillips, S. J. and Comus, P. W. (eds.). 2000. A Natural History of the Sonoran Desert. Tucson: Arizona-Sonora Desert Museum Press. Berkeley: University of California. 9-10.

SALE, p. 1991. Dwellers in the Land. Bioregional Vision. Philadelphia: New Society

Slovic, S. 2008. "Foreword”. Xerophilia. Ecocritical Explotarions in Southwestern Literature. T. LYNCH. Texas: Texas Tech University Press. $x \mathrm{x}$.

SpIVAK, Ch. G. 1995. “Translator's Note”, Translator's Preface”. Three Stories. Imaginary Maps. I. DEVI ed. New York: Rouledge. xxv-xxix

Thayer, R. L. 2003. LifePlace: Bioregional Thought and Practice. Berkley: University of California Press. 3.

Tuan, Y. F. 2007. Topofilia. Madrid: Melusina. 87.

VALERo GARCES, C. 2010. "Reflexiones en torno a ecocrítica, traducción y terminología". Ecocríticas. Literatura y medioambiente. C. FLYS, J. M. MARRERO and J. BARELLA eds. Madrid: Iberoamericana. 121-134.

Williams, T. T. 2001. Red. Passion and Patience in the Desert. New York: Pantheon Books. 136 